OPEN ACCESS

Edited by:

Pedro Bekinschtein,

Institute of Cognitive and Translational

Neuroscience (INCYT), Argentina

Reviewed by:

Jose Antonio Gomez-Sanchez,

University College London,

United Kingdom

Kristjan R. Jessen,

University College London,

United Kingdom

*Correspondence:

Fei Zhu

hfzfzx@163.com

Wei Wang

drprsdavidwang@outlook.com

${ }^{\dagger}$ These authors have contributed equally to this work

Specialty section:

This article was submitted to

Non-Neuronal Cells,

a section of the journal

Frontiers in Cellular Neuroscience

Received: 19 January 2019

Accepted: 21 June 2019

Published: 09 July 2019

Citation:

Chen G, Luo X, Wang W, Wang Y,

Zhu F and Wang W (2019)

Interleukin-1 $\beta$ Promotes Schwann Cells De-Differentiation in Wallerian

Degeneration via the C-JUN/AP-1

Pathway.

Front. Cell. Neurosci. 13:304. doi: 10.3389/fncel.2019.00304

\section{Interleukin-1 $\beta$ Promotes Schwann Cells De-Differentiation in Wallerian Degeneration via the C-JUN/AP-1 Pathway}

\author{
Gang Chen ${ }^{1 \dagger}$, Xiaohe Luo ${ }^{2 \dagger}$, Wenjin Wang ${ }^{1}$, Yimei Wang ${ }^{3}$, Fei Zhu ${ }^{2 *}$ and Wei Wang ${ }^{1 *}$ \\ ${ }^{1}$ Department of Plastic and Reconstructive Surgery, Shanghai Ninth People's Hospital, Shanghai Jiao Tong University \\ School of Medicine, Shanghai, China, ${ }^{2}$ Department of Plastic Surgery, First Affiliated Hospital of Anhui Medical University, \\ Hefei, China, ${ }^{3}$ Department of Plastic Surgery, First Affiliated Hospital of Nanchang University, Nanchang, China
}

Schwann cells (SCs) de-differentiate in Wallerian degeneration (WD) following nerve injury and, by doing so, can actively promote nerve repair and functional recovery. An innate-immune response is an important component of the complex of events referred to as WD. Damaged peripheral nervous system SCs produce IL-1 $\beta$ and other inflammatory cytokines. We hypothesized that, in addition to a role in immune responses, IL-1 $\beta$ participates in de-differentiation and proliferation of SCs. qPCR and ELISA demonstrated that expression of $\mathrm{IL}-1 \beta$ mRNAs and protein increased after nerve injury. Immunofluorescent staining and western blotting demonstrated that expression of the p75 neurotrophin receptor (p75NTR) was significantly increased and levels of myelin protein zero (MPZ) were significantly decreased after IL-1 $\beta$ exposure compared with control groups in vitro WD. Additionally, qPCR demonstrated that IL-1 $\beta$ elevated expression of the de-differentiation gene p75NTR and decreased expression of myelination locus MPZ and promoted SCs de-differentiation. Furthermore, immunofluorescent staining, western blotting, qPCR and ELISA revealed that IL-1 $\beta$ promoted c-JUN expression and activation of AP-1 activity of SCs in an in vitro WD model. Finally, Immunofluorescent staining illustrated that IL-1 $\beta$ elevated expression of Ki67 in SCs nuclei, the apoptosis of SCs were detected by TUNEL. SCs of WD produce $\mathrm{IL}-1 \beta$ which promotes SCs de-differentiation and proliferation.

\section{Keywords: Wallerian degeneration, Schwann cells, IL-1ß, MPZ, p75NTR, c-JUN/AP-1, de-differentiation}

\section{INTRODUCTION}

The ultimate goal of regenerative medicine research is to enable replacement of lost or damaged tissues or organs. Regeneration can potentially be accomplished using the processes of dedifferentiation, trans-differentiation or reprogramming. Humans have a limited capacity to regenerate tissues or organs, including liver and the peripheral nervous system (PNS). These tissues respond to injury through cellular reprogramming, producing cells that specifically promote repair and regeneration (Jessen and Arthur-Farraj, 2019). In some cases, the process of regeneration

Abbreviations: DAPI, 4'6-diamino-2-phenyl indole; PNS, peripheral nervous system; RT, reverse transcription; SCs, Schwann cells; SNs, sciatic nerves; WD, Wallerian degeneration. 
involves de-differentiation of mature cells. De-differentiation is a mechanism in which terminally differentiated cells revert to a less-differentiated stage within the same lineage and allows cells to proliferate before re-differentiating, leading to the replacement of lost cells (Jopling et al., 2011).

Schwann cells (SCs), myelinated glial cells of the PNS, de-differentiate and convert to denervated SCs in Wallerian degeneration (WD) following nerve injury and, by doing so, can actively promote nerve repair and functional recovery (Jessen and Mirsky, 2008; Tricaud and Park, 2017) So, it is also described as repair SCs. Meanwhile, they activate a series of repair-related phenotypes (Jessen and Mirsky, 2016; Jessen and Arthur-Farraj, 2019). Following de-differentiation, SCs clear myelin debris by autophagy, in addition, SCs contribute to macrophage-mediated myelin removal and re-enter the cell cycle, proliferate, and then form bands of Büngner, which support and direct outgrowing axons to sites of innervation (Martini et al., 2008; Rotshenker, 2011; Brosius et al., 2017). Moreover, these cells express and secrete a large number of axonal growth promoting factors, then re-differentiate and myelinate regenerated axons, which eventually leads to substantial functional recovery (WoszczyckaKorczynska et al., 2013; Jessen and Mirsky, 2016). Damaged SCs may induce cell apoptosis and limit functional recovery of peripheral nerves (Zhao et al., 2017). This sequence emphasizes the central function of SC de-differentiation in PNS regeneration.

An innate-immune response is an important component of the complex of events referred to as WD. PNS injury induces immune and non-immune cells to produce cytokines and develop an efficient cytokine network during WD (Rotshenker et al., 1992; Be'Eri et al., 1998; Shamash et al., 2002). Before macrophage recruitment, injured PNS produce IL-1 $\beta$ and other inflammatory cytokines (Rotshenker, 2011). These inflammatory cytokines have an irreplaceable effect on the initiation and regulation of inflammation during injury (Bastien and Lacroix, 2014). Certain inflammatory cytokines can influence de-differentiation in some types of terminally differentiated cells. For example, IL-1 $\beta$ induces chondrocyte de-differentiation (Montaseri et al., 2011; Hong et al., 2014), and some scholars demonstrate that IL-1 $\beta$ also increases vascular smooth muscle cells de-differentiation and proliferation (Sasu and Beasley, 2000; Clement et al., 2006; Zhu et al., 2007). We hypothesized that, in addition to a role in immune responses, IL- $1 \beta$ participates in SC de-differentiation and proliferation. We used a rodent in vitro WD model to investigate effects of IL- $1 \beta$ on SC dedifferentiation, excluding effects of immune cells and other inflammatory cytokines.

\section{MATERIALS AND METHODS}

\section{In vitro WD Model}

The Ethics Committee for Animal Research at the Ninth People's Hospital affiliated to Shanghai Jiao Tong University approved all experimental protocols involving the use of rats. Sciatic nerve (SN) explant cultures were performed as previously reported by Thomson et al. (1993) with minor modifications (Thomson et al., 1993; Lee et al., 2009). Eight-week old male Sprague-Dawley rats, obtained from the Ninth People's Hospital Animal Center, Shanghai, China, were euthanized with $10 \%$ chloral hydrate. SNs were exposed and carefully cut, and WD induced by nerve injury. Connective tissues surrounding the SNs and epineurium were carefully detached in DMEM under a stereomicroscope (Carl Zeiss). SNs were dissected into explants $1 \mathrm{~cm}$ in length. SN explants were established by loosely separating small bundles of fibers from the isolated nerve. The bundles of nerve were maintained in DMEM containing 10\% fetal bovine serum, $100 \mathrm{U} / \mathrm{ml}$ penicillin, $100 \mathrm{mg} / \mathrm{ml}$ streptomycin and $0.25 \mathrm{mg} / \mathrm{ml}$ amphotericin $\mathrm{B}$ at $37^{\circ} \mathrm{C}$ with $5 \% \mathrm{CO}_{2}$. Cell culture reagents were obtained from Invitrogen. Nerve bundles were treated with or without various concentrations of recombinant rat IL-1 $\beta$ (401ML-025, R\&D Systems).

Schwann cells and fibroblasts compose most of the nonneuronal cell population in intact PNS, whereas macrophages, which are scarce in intact PNS, are recruited in large numbers from the third day after injury (Perry et al., 1987; Reichert et al., 1994). In our modified in vitro WD model, in which epineurium were carefully detached, SCs comprise the majority of the cell population in this model and are the primary object of this study.

\section{RNA Extraction, RT-qPCR, and qPCR Analysis}

Total RNA was isolated from SNs in the in vitro WD model. Briefly, SNs were washed with PBS and lysed with TRIzol reagent (Invitrogen), according to the manufacturer's protocol. $2 \mathrm{mg}$ of total RNA was used for reverse transcription (RT), and the products used in qPCR. Target genes were quantified with an ABI 7500 Real-Time PCR System (Life Technologies). PCR primer pairs were designed based on sequences of different exons of the corresponding genes (Table 1). All PCR amplifications were performed with an initial denaturation at $95^{\circ} \mathrm{C}$ for $10 \mathrm{~s}$, followed by 40 cycles at $95^{\circ} \mathrm{C}, 30 \mathrm{~s}, 60^{\circ} \mathrm{C}, 30 \mathrm{~s}$, followed by melting curve analysis at $95^{\circ} \mathrm{C}, 60 \mathrm{~s}$ and $60^{\circ} \mathrm{C}, 30 \mathrm{~s}$.

\section{Quantification of IL-1 $\beta$ by ELISA}

Fifteen $30 \mathrm{~mm}$ SN segments without epineurium were harvested from rats. Three SN segments were frozen immediately in liquid nitrogen. The remainder were cultured as per the in vitro WD model. These nerve segments were harvested after 12, 24, 36, and $48 \mathrm{~h}$. Nerve segments were extracted in $1 \mathrm{ml}$ PBS containing a mixture of protease inhibitors (Roche Molecular Biochemicals).

TABLE 1 | List of oligonucleotides used for quantitative real time PCR.

\begin{tabular}{lll}
\hline Target gene & Sequence & References \\
\hline Rat IL-1 $\beta$ & 5' AGT GTG TGA TGT TCC CAT TAG 3' & NM_031512.2 \\
Rat p75NTR & 5' GCT TAT GTT CTG TCC ATT GAG 3' & \\
Rat MPZ & 5' TGC CTT TCT CTG GGT TT AC 3' & NM_012610.2 \\
& 5' CAT TGT GGT TTA CAC GGA CAG 3' & NM_017027.1 \\
Rat C-JUN & 5' CTT GGC ATA GTG GAA GAT TGA 3' & \\
& 5' TGA AGT GAC CGA CTG TTC TAT 3' & NM_021835.3 \\
& 5' CTT AGG GTT ACT GTA GCC GTA G 3' &
\end{tabular}


We used two-site sandwich ELISA to identify and quantify IL$1 \beta$ in SNs, according to the manufacturer's instructions (Duo-Set; R\&D Systems). SNs were rinsed in ice-cold PBS to remove excess blood. Tissues were minced and homogenized in $1 \mathrm{ml}$ PBS with a glass tissue grinder on ice. The resulting suspension was subjected to ultrasonication to further disrupt cell membranes. Homogenates were centrifuged for $15 \mathrm{~min}$ at $1500 \times g$ and supernatants used for ELISA.

\section{Immunofluorescent Staining}

Teased nerve fibers mounted on slides were treated with PBS containing 4\% Paraformaldehyde for $30 \mathrm{~min}$ and blocked with PBS containing $0.2 \%$ Triton X-100 and $2 \%$ BSA for $60 \mathrm{~min}$. Nerve fibers were incubated with primary antibody (antip75NTR antibody 1:1000, ab52987, Abcam; anti-myelin protein zero (MPZ) antibody, 1:1000, ab31851, Abcam; anti-c-JUN antibody, 1:1000, \#9165, Cell Signaling; anti-Ki67 antibody,1:100, ab16667, Abcam) for $16 \mathrm{~h}$ at $4^{\circ} \mathrm{C}$ and washed three times with PBS. Next, slides were incubated with Alexa 549- or 488conjugated secondary antibody (1:800, Alexa Fluor) for $2 \mathrm{~h}$ at room temperature and washed three times with PBS. Finally, slides were incubated with PBS counterstained with 4'6-diamino2-phenyl indole (DAPI; Vectashield, Vector Laboratories) to visualize nuclei. DAPI staining was used for enumeration and identification of nuclei. The slides were visualized using a 20×/0.50 Plan-Neofluar lens (Carl Zeiss). c-JUN-positive endonuclear cells were counted to analyze percent of c-JUN $(+)$ in three independent experiments. Ki67-positive endonuclear cells were counted to analyze percent of Ki67 (+)in three independent experiments.

\section{Western Blotting}

Proteins were extracted with RIPA lysis buffer containing $1 \mathrm{mM}$ PMSF (Beyotime) and $40 \mathrm{mM}$ protease inhibitor (Roche Molecular Biochemicals). Lysates were cleared by centrifugation at $14,000 \mathrm{rpm}$ for $5 \mathrm{~min}$ at $4^{\circ} \mathrm{C}$. Protein concentrations were measured using a BCA protein assay kit (Pierce Chemicals) according to the manufacturer's protocol. Reducing buffer was added to each protein extract and samples heated to $100^{\circ} \mathrm{C}$ for 5 min. Reduced samples containing equal amounts of protein were resolved by SDS-PAGE and transferred to a nitrocellulose membrane. The membrane was blocked in 5\% BSA and probed with anti-p75NTR, anti-MPZ, and anti-c-JUN antibodies. Blots were washed, incubated with horseradish peroxidase-conjugated secondary antibody (Santa Cruz Biotechnology), and developed with ECL Plus (Amersham Biosciences). Filters were stripped and probed with a goat polyclonal antibody against $\beta$-actin (Santa Cruz Biotechnology) to assess equivalent protein loading and to normalize protein levels. Protein bands were analyzed using a chemiluminescence kit (Santa Cruz Biotechnology) and visualized using BandScan 5.0 software western immunoblotting detection system.

\section{AP-1 Activity Assay}

The AP-1 activity assay was used to examine AP-1 activity of SCs in the in vitro WD model with or without $5 \mathrm{ng} / \mathrm{ml}$ at 6,12 , and $24 \mathrm{~h}$. The DNA binding activity of AP-1 was determined using an AP-1 enzyme-linked immunosorbent assay kit essentially as instructed by the manufacture (Active Motif North America). Briefly, samples in each group were lysed in $10 \mathrm{mM}$ HEPES buffer, pH 7.9, containing $10 \mathrm{mM} \mathrm{KCl,} 0.1 \mathrm{mM}$ EDTA, $0.1 \mathrm{mM}$ EGTA, $1 \mathrm{mM}$ dithiothreitol, and inhibitors of proteases as described above. After the addition of $0.6 \%$ (v/v) Nonidet P-40, the samples were incubated for $15 \mathrm{~s}$ on ice and then centrifuged at $13,000 \times g$ for $30 \mathrm{~s}$ at $4^{\circ} \mathrm{C}$. The pellet was suspended in the supplied nuclear lysis buffer and centrifuged at $13,000 \times g$ for $10 \mathrm{~min}$ at $4^{\circ} \mathrm{C}$. Nuclear protein $(10 \mu \mathrm{g})$ was loaded into the 96-wells of an enzyme-linked immunosorbent assay plate pre-coated with an oligonucleotide containing the sequence $5^{\prime}$-TGAGTCAG- $3^{\prime}$ and incubated for $60 \mathrm{~min}$ at room temperature. Mutated c-JUN oligonucleotides supplied in the kit were used as specificity controls. AP-1 binding to the nucleotide was detected with an anti-phospho-c-JUN antibody and horseradish peroxidaseconjugated secondary antibody followed by colorimetric analysis.

\section{TUNEL Staining of Apoptosis}

Teased nerve fibers mounted on slides were treated with PBS containing 4\% Paraformaldehyde for $15 \mathrm{~min}$, discarded with fixative solution and washed with PBS for 3 times. Next, slides were incubated with $0.1 \%$ sodium citrate buffer solution and $0.1 \%$ Trion $\times 100$ for 2 min on ice. Rinse slides three times with PBS and add TUNEL reaction mixture (Roche Molecular Biochemicals) on nerve fibers for $60 \mathrm{~min}$ in the dark. Rinse slides three times with PBS. Finally, slides were incubated with PBS counterstained with $4^{\prime} 6$-diamino-2-phenyl indole (DAPI; Vectashield, Vector Laboratories) to visualize nuclei. DAPI staining was used for enumeration and identification of nuclei. The slides were visualized using a $20 \times / 0.50$ Plan-Neofluar lens (Carl Zeiss). The TUNEL labeled red and DAPI labeled blue were positive at the same time as apoptosis.

\section{Statistical Analysis}

Data are expressed as the means \pm SE. Each independent experiment was repeated three times. The significance of differences between two independent samples was statistically assessed using Student's $t$-test. The statistical significance of differences between groups was determined by one-way ANOVA followed by the Least Significant Difference (LSD) test. $p$-values $<0.05$ were considered significant.

\section{RESULTS}

\section{IL-1 $\beta$ mRNA Expression and IL-1 $\beta$ Protein Production by SCs in in vitro WD Model}

Sciatic nerves without epineurium were frozen immediately after removal from rats, as a control group. SNs were cultured as per in vitro WD model and harvested at different times. These SN tissues were used thereafter as sources for the detection of IL-1 $\beta$ mRNA expression and IL-1 $\beta$ protein production by SCs. Relative quantification of IL-1 $\beta$ mRNA was performed by qPCR, and results were analyzed by one-way ANOVA followed by LSD test (Figure 1A). The analysis revealed expression of IL-1 $\beta$ mRNA by SCs increased after SN injury, peaking at $12 \mathrm{~h}$. 

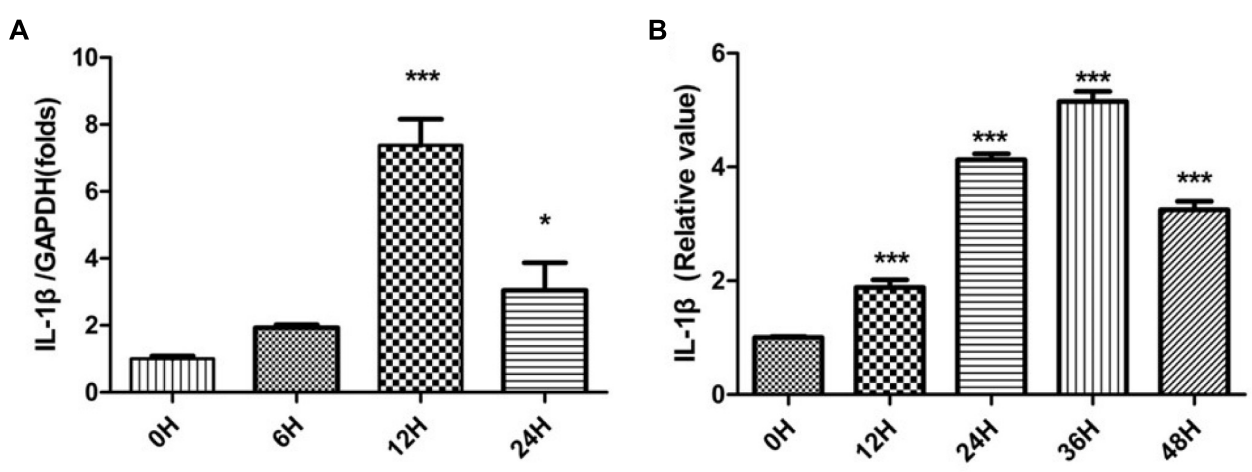

FIGURE 1 | IL-1 $\beta$ mRNA expression and IL-1 $\beta$ protein production. The relative quantification of IL-1 $\beta$ mRNA was performed by qPCR (A) and IL-1 $\beta$ protein levels were determined by ELISA (B) in SCs. The control group is labeled as $0 \mathrm{~h}$. SCs harvested from SNs at different times were compared to the control group. ${ }^{*} p<0.05,{ }^{* * *} p<0.001$.

IL- $1 \beta$ exerts its biological activity as a soluble molecule only. We further tested for the presence of soluble IL-1 $\beta$ using ELISA. Expression levels of soluble IL-1 $\beta$ by SCs were compared with quantities in SNs. Relative values of IL-1 $\beta$ were analyzed by one-way ANOVA followed by LSD test (Figure 1B). Production of soluble IL-1 $\beta$ protein by SCs increased after nerve damage, peaking at $36 \mathrm{~h}$.

\section{Effect of IL-1 $\beta$ on De-Differentiation of SCs}

Sciatic nerve SCs were treated with various concentrations of recombinant rat $\mathrm{IL}-1 \beta(0,5$, and $50 \mathrm{ng} / \mathrm{ml})$ in this in vitro WD model and harvested after $48 \mathrm{~h}$. We detected expression of p75NTR, a marker of SC de-differentiation (Jessen and Mirsky, 2008; Shin et al., 2013), and MPZ, an essential factor in myelination in these SNs to assess SCs de-differentiation (Warner et al., 1998). Immunofluorescent staining demonstrated that expression of p75NTR increased and levels of MPZ decreased in the $5 \mathrm{ng} / \mathrm{ml}$ IL-1 $\beta$ group compared with 0 and $50 \mathrm{ng} / \mathrm{ml}$ groups (Figures 2A,B) at $48 \mathrm{~h}$. Additionally, the difference of p75NTR and MPZ expression between the 50 and $0 \mathrm{ng} / \mathrm{ml}$ IL- $1 \beta$ groups is not obvious. These were quantitatively verified by western blotting, with results analyzed by one-way ANOVA followed by LSD test (Figures $2 \mathrm{C}-\mathbf{E}$ ). $5 \mathrm{ng} / \mathrm{ml} \mathrm{IL-1 \beta}$ promoted SCs dedifferentiation. Nevertheless, a high concentration $(50 \mathrm{ng} / \mathrm{ml})$ IL-1 $\beta$ did have the similar effect.

\section{Effect of IL-1 $\beta$ on Expression of p75NTR and MPZ mRNAs by SCs in in vitro WD Model}

As $5 \mathrm{ng} / \mathrm{ml}$ IL- $1 \beta$ promoted SC de-differentiation, we further quantified expression of p75NTR and MPZ mRNAs by SCs in the present in vitro WD model. We harvested SCs from SNs with or without $5 \mathrm{ng} / \mathrm{ml} \mathrm{IL-1 \beta}$ at 6,12 , and 24 h. qPCR demonstrated that expression of p75NTR mRNA increased in a time-dependent manner in each concentration group, and was elevated more significantly in the $5 \mathrm{ng} / \mathrm{ml}$ group compared with the $0 \mathrm{ng} / \mathrm{ml}$ group (Figure $3 \mathbf{A}$ ).
Additionally, expression of MPZ mRNA decreased in a temporal manner in both concentration groups, and further decreased in the $5 \mathrm{ng} / \mathrm{ml}$ group compared with the $0 \mathrm{ng} / \mathrm{ml}$ group (Figure 3B). This suggested that $5 \mathrm{ng} / \mathrm{ml}$ IL-1 $\beta$ increased expression of the de-differentiation gene p75ntr and decreased expression of myelination locus MPZ, promoting SCs de-differentiation.

\section{Effect of IL-1 $\beta$ on C-JUN and AP-1 Activity in SCs}

The transcription factor $\mathrm{c}$-JUN is a global regulator of WD and SCs de-differentiation (Arthur-Farraj et al., 2012; Jessen and Mirsky, 2016) and plays a role in demyelination after PNS injury (Parkinson et al., 2008; Lee et al., 2014). Additionally, these functions of c-JUN were localized in SC nuclei. Therefore, we firstly used immunofluorescent staining to detect the expression of $\mathrm{c}$-JUN in SC nuclei. SCs exposed or not to $5 \mathrm{ng} / \mathrm{ml}$ IL- $1 \beta$ were harvested after 24 h. Immunofluorescent staining demonstrated that levels of c-JUN in SC nuclei increased in the $5 \mathrm{ng} / \mathrm{ml}$ group compared with the $0 \mathrm{ng} / \mathrm{ml}$ group. This was quantitatively verified by percent analysis of endonuclear c-JUN $(+)$ cells (Figures 4A,B). In addition, western blot analysis also revealed that expression of c-JUN in SCs was significantly increased in the $5 \mathrm{ng} / \mathrm{ml}$ group in comparison to the $0 \mathrm{ng} / \mathrm{ml}$ group (Figures 4C,D). To further verify effects of IL-1 $\beta$ on $c-J U N$ expression, we used qPCR to detect expression of c-JUN mRNA in SCs in our in vitro WD model with or without $5 \mathrm{ng} / \mathrm{ml} \mathrm{IL}-1 \beta$ at 6,12 , and $24 \mathrm{~h}$. qPCR demonstrated that expression of c-JUN mRNA increased in a time-dependent manner in both concentration groups, and increased more significantly in the $5 \mathrm{ng} / \mathrm{ml}$ group compared with the $0 \mathrm{ng} / \mathrm{ml}$ group at $24 \mathrm{~h}$ (Figure 4E). These results suggested that $5 \mathrm{ng} / \mathrm{ml} \mathrm{IL-1 \beta}$ increased expression of $\mathrm{c}$-JUN and $\mathrm{c}$-JUN transcription factor, and elevated the proportion of endonuclear c-JUN $(+)$ cells in SCs.

The transcription factor c-JUN is a component of the heterodimeric AP-1 transcription factor complex and c-JUN/AP-1 are highly expressed in response to neuronal 

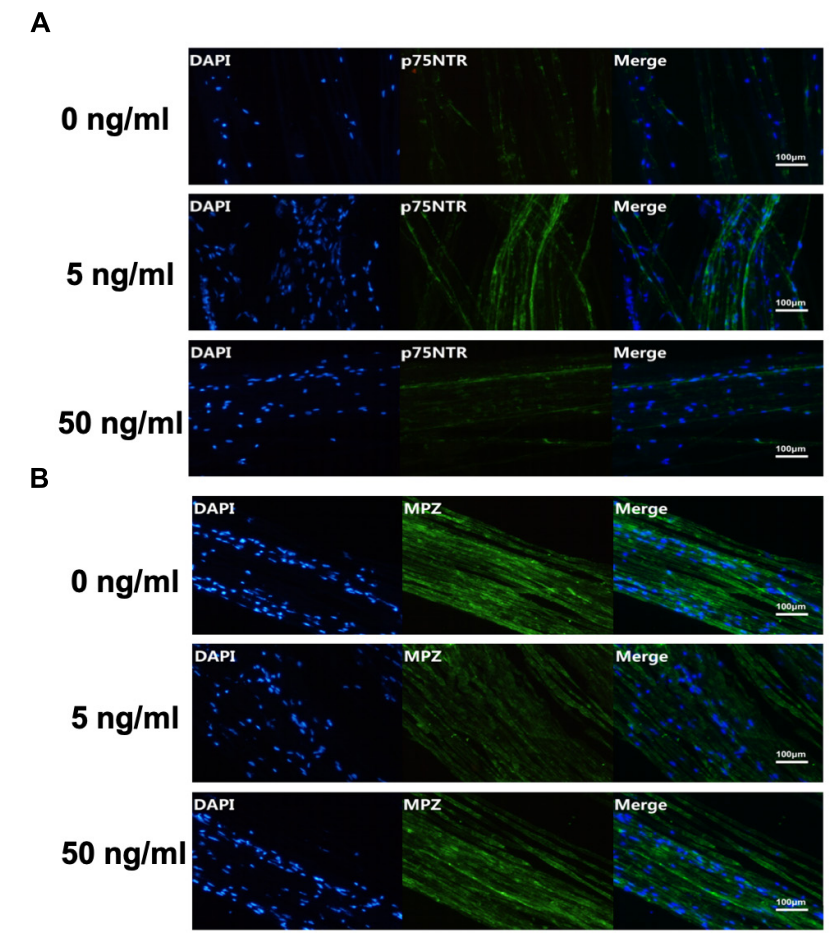

C
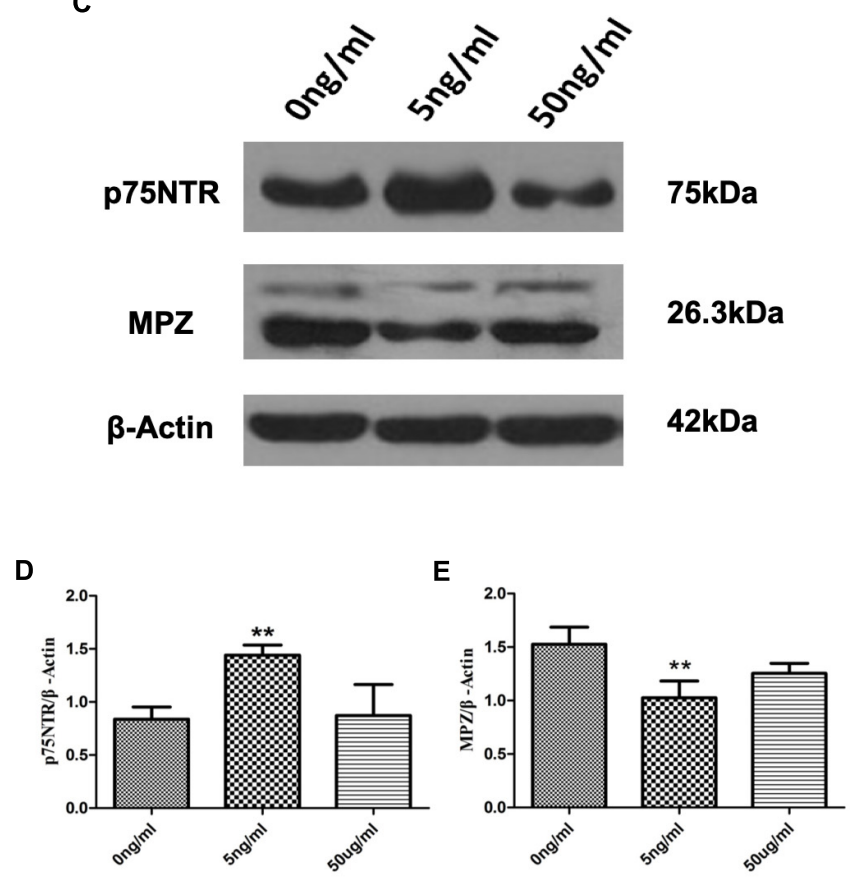

FIGURE 2 | Expression of p75NTR and MPZ in the in vitro WD model at $48 \mathrm{~h}$. Immunofluorescent staining of p75nNTR (A) and MPZ (B), and western blotting to quantitatively analyze expression levels (C-E) in SCs with various concentrations of IL-1 $\beta$ at $48 \mathrm{~h}$. Results are means \pm SE $(n=3$ per group) from independent experiments. ${ }^{* *} p<0.01$.
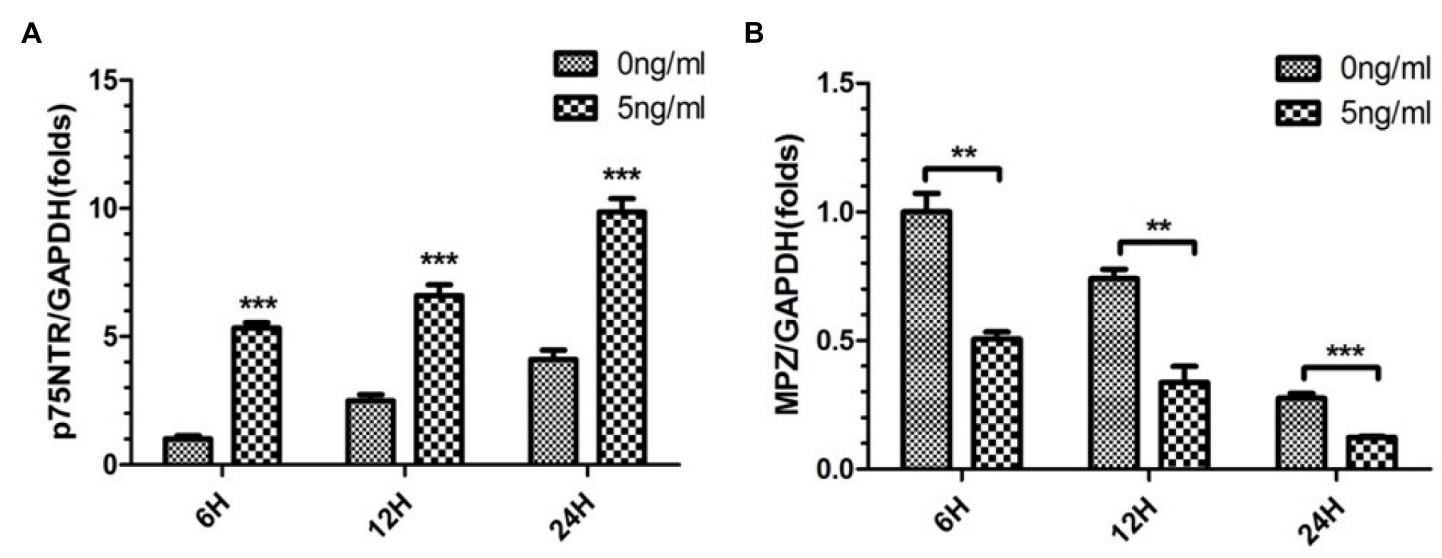

FIGURE 3 | Expression of p75NTR and MPZ mRNA in the in vitro WD model. qPCR was used to quantitatively analyze expression of p75NTR (A) and MPZ mRNAs (B) with or without $5 \mathrm{ng} / \mathrm{ml} \mathrm{IL-1 \beta}$ at 6,12 , and $24 \mathrm{~h}$. Results are means $\pm \mathrm{SE}$ ( $n=3$ per group) from independent experiments. ${ }^{* *} p<0.01$, *** $p<0.001$.

trauma (Raivich et al., 2004). We therefore examined AP-1 activity of SCs in the in vitro WD model with or without $5 \mathrm{ng} / \mathrm{ml} \mathrm{IL-1} \beta$ at 6,12 , and $24 \mathrm{~h}$ using an AP- 1 activity assay. This indicated that AP-1 activity increased in a timedependent manner in both concentration groups, and was more significantly increased at 12 and $24 \mathrm{~h}$ in the $5 \mathrm{ng} / \mathrm{ml}$ group compared with the non-exposed group (Figure 4F). AP-1 activity assay results, combined with analyses of c-JUN, suggested that $5 \mathrm{ng} / \mathrm{ml} \mathrm{IL-1 \beta}$ promoted endonuclear
c-JUN expression and stimulation of AP-1 activity in our in vitro WD model.

\section{Effect of IL-1 $\beta$ on Proliferation and Apoptosis of SCs}

We harvested SCs from SNs with or without $5 \mathrm{ng} / \mathrm{ml} \mathrm{IL-1 \beta}$ after $24 \mathrm{~h}$. Then, we firstly used immunofluorescent staining to detect the expression of Ki67 in SC nuclei. This demonstrated 




B

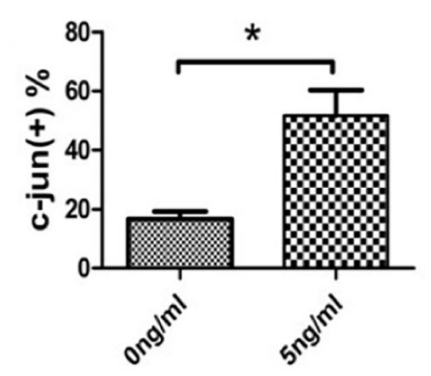

C

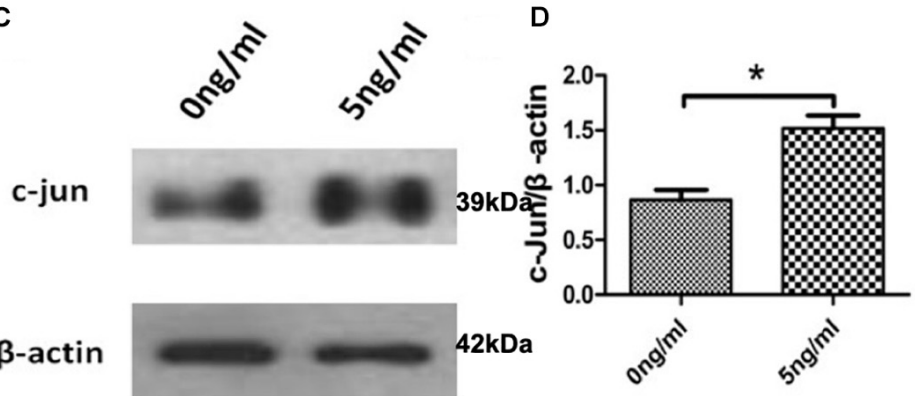

E

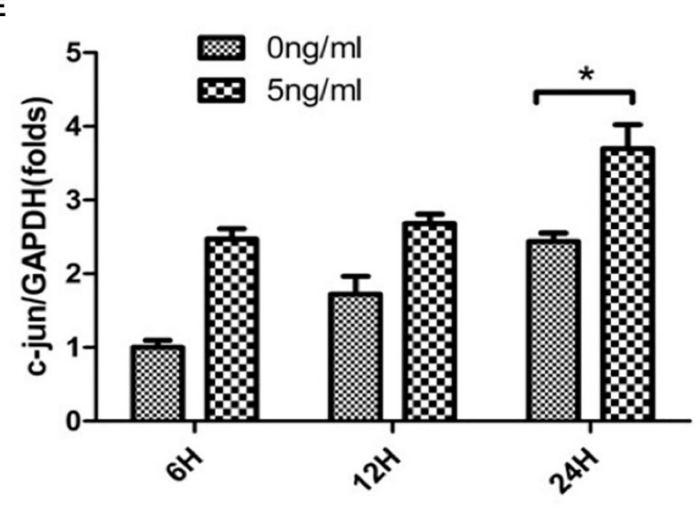

\begin{abstract}
$F$
\end{abstract}



FIGURE 4 | C-JUN and AP-1 activity assay in the in vitro WD model. Immunofluorescent staining of C-JUN (A, arrows indicate c-JUN(+) cells), analysis of percentage of endonuclear C-JUN(+) cells (B), and western blotting to quantitatively analyze expression of C-JUN (C,D) in SCs with or without 5 ng/ml IL-1 $\beta$ at 24 h. qPCR was used to quantitatively analyze expression of C-JUN mRNA (E), and AP-1 activity assay to quantitatively analyze activity (F) of SCs in the in vitro WD model with or without $5 \mathrm{ng} / \mathrm{ml} \mathrm{IL-1 \beta}$ at 6,12 and $24 \mathrm{~h}$. Results are means \pm SE ( $n=3$ per group) from independent experiments. ${ }^{*} p<0.05$.

that levels of Ki67 in SCs nuclei increased in the $5 \mathrm{ng} / \mathrm{ml}$ group with the $0 \mathrm{ng} / \mathrm{ml}$ group. This was quantitatively verified by percent analysis of endonuclear Ki67(+) cells, and the percent was increased in the $5 \mathrm{ng} / \mathrm{ml}$ group compared with the $0 \mathrm{ng} / \mathrm{ml}$ group at $48 \mathrm{~h}$ (Figures 5A,C). After that, we used TUNEL to detect the percentage of SCs apoptosis. SCs harvested from in vitro WD model treated with or without $5 \mathrm{ng} / \mathrm{ml} \mathrm{IL}-1 \beta$ after $48 \mathrm{~h}$. TUNEL demonstrated that percentage of SCs apoptosis decreased in the $5 \mathrm{ng} / \mathrm{ml}$ group compared with the $0 \mathrm{ng} / \mathrm{ml}$ group (Figures 5B,D).

\section{DISCUSSION}

In a reminiscent process of the injury responses of zebrafish cardiomyocytes or pigment cells of the newt iris, nerve injury 
A
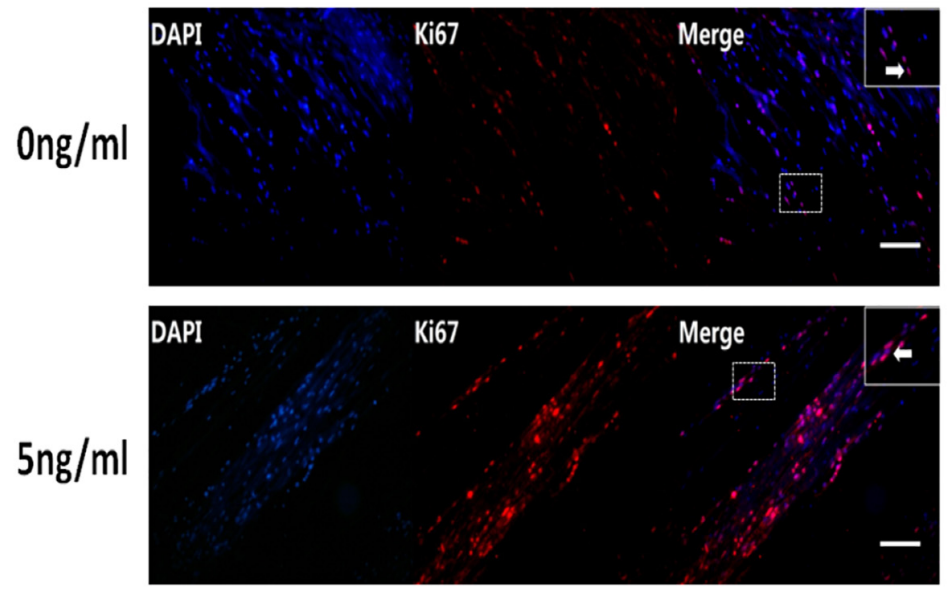

B

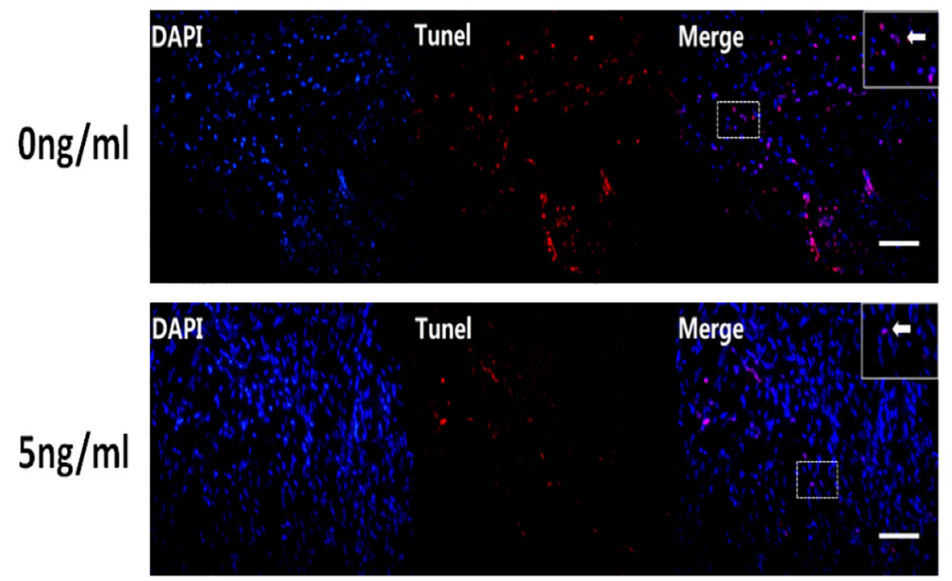

C

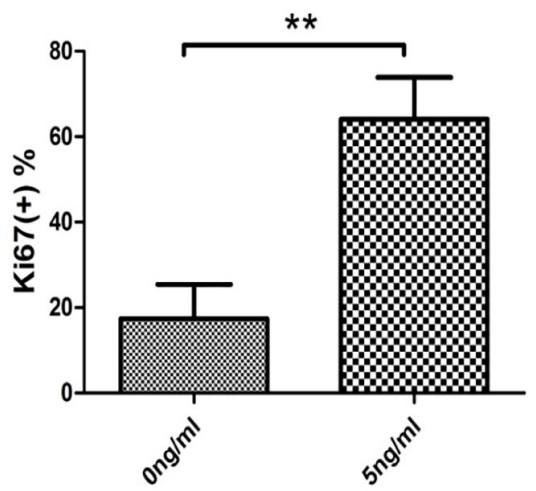

D



FIGURE 5 | Expression of Ki67 and TUNEL in the in vitro WD model. Immunofluorescent staining of Ki67 (A, arrows indicate Ki67(+) cells), analysis of percentage of endonuclear Ki67(+) cells (C) in SCs with or without $5 \mathrm{ng} / \mathrm{ml} \mathrm{IL-1 \beta}$ at $48 \mathrm{~h}$. TUNEL staining of apoptosis cells (B, arrows indicate apoptosis cells), analysis of percentage of TUNEL(+) cells (D) in SCs in the in vitro WD model with or without $5 \mathrm{ng} / \mathrm{ml} \mathrm{IL-1 \beta}$ at $48 \mathrm{~h}$. Results are means \pm SE $(n=3$ per group) from independent experiments. ${ }^{*} p<0.05,{ }^{* *} p<0.01$

and loss of axonal contact causes mammalian SCs to lose their differentiated morphology, down-regulate myelin gene expression, up-regulate markers of immature SCs, and re-enter the cell cycle (Arthur-Farraj et al., 2012). During WD, SCs de-differentiate and up-regulate genes implicated in promoting axon growth, neuronal survival, and macrophage invasion, and break down their myelin sheaths by autophagy and phagocytosis, and morphologically transform into cells with long, parallel neural processes (Chen et al., 2007; Vargas and Barres, 2007; Gordon et al., 2009; Brosius et al., 2017). SCs de-differentiation allows them to form uninterrupted regeneration tracks (Bands of Büngner) that guide axons back to their targets, and provides a permissive environment for nerve regeneration (Vargas and Barres, 2007; Allodi et al., 2012). Although WD responses, including those resulting from SC injury, are key to damage repair, the molecular mechanisms that control these processes has remained uncertain.

Here, our research showed that the expression of IL- $1 \beta$ mRNA and protein increased in SCs after nerve injury, with IL- $1 \beta$ mRNA peaking at $12 \mathrm{~h}$ and IL- $1 \beta$ protein maximal by $36 \mathrm{~h}$ in this in vitro WD model. These results of our study are similar to previous reports for in vivo WD.

To test the hypothesis that, in addition to a role in immune responses, IL-1 $\beta$ participates in SC de-differentiation, we used the in vitro WD model treated with various concentrations of IL-1 $\beta$ to investigate effects on SC de-differentiation. Our study suggested that a specific concentration of IL-1 $\beta(5 \mathrm{ng} / \mathrm{ml})$ increased expression of p75NTR and decreased levels of MPZ. Nevertheless, a high concentration $(50 \mathrm{ng} / \mathrm{ml})$ IL- $1 \beta$ did have the similar effect. SCs in immature states re-express p75NTR, which is a marker of SC de-differentiation (Jessen and Mirsky, 2008; Shin et al., 2013). During de-differentiation, SCs cease to express myelin genes, including MPZ (Warner et al., 1998; Jang et al., 2017). Up-regulation of p75NTR and down-regulation of MPZ have been implicated in SCs de-differentiation and regeneration. Thus, our study suggested that an appropriate concentration of IL-1 $\beta$ promoted SCs de-differentiation and regeneration in WD. On the contrary, a too high concentration of IL- $1 \beta$ might 
deactivate SCs and could not promote SCs de-differentiation and regeneration in WD.

Previous studies indicate that IL- $1 \beta$ causes de-differentiation of primary cultured articular chondrocytes via the c-JUN/AP1 pathway (Hwang et al., 2005). On the other hand, IL-1 $\beta$ can induce differentiation of precursor cells. For example, IL-1 $\beta$ is an essential factor for maturation of endothelial precursor cells to ECs (Voronov et al., 2014). However, our research is the first to report that IL-1 $\beta$ promotes SCs de-differentiation in WD. At the same time, there are some reports indicating that IL-1 $\beta$ promotes neurite outgrowth by deactivating RhoA via the p38 MAPK pathway (Temporin et al., 2008a) and sensory nerve regeneration after SN injury (Temporin et al., 2008b). Before and after macrophage recruitment, WD can be defined as two phases characterized by cytokine protein production profiles. The first phase is characterized by the synthesis of IL-1 $\beta$ and other inflammatory cytokines (such as TNF- $\alpha$, IL$1 \alpha$, GM-CSF and IL-6). The second phase is characterized by the production of Il-10, Il-6, and a GM-CSF inhibitor molecule, and furthermore, by the diminished production of IL-1 $\beta$. Therefore, the first phase is largely inflammatory and the second is predominantly anti-inflammatory (Rotshenker, 2011). Thus, based on our research and previous reports, we interpret that appropriate concentrations of IL-1 $\beta$ are conductive to de-differentiation and regeneration of SCs during the first phase of WD.

The transcription factor $\mathrm{c}$-JUN is a key regulator of WD, governs major aspects of injury response, determines the expression of trophic factors, adhesion molecules, the formation of regeneration tracks and myelin clearance and controls the distinctive regenerative potential of peripheral nerves. A key function of $\mathrm{c}$-JUN is the activation of a repair program in SCs and the creation of a cell specialized to support regeneration (Arthur-Farraj et al., 2012; Boerboom et al., 2017). In our study, immunofluorescent microscopy revealed that expressed c-JUN was localized mainly in SC nuclei, consistent with its function as a component of the AP-1 transcription factor. In addition, the endonuclear c-JUN $(+)$ cells fraction of IL-1 $\beta(5 \mathrm{ng} / \mathrm{ml})$ treated group was significantly higher than ration of control group. Furthermore, expression of c-JUN protein and mRNA each significantly increased in IL- $1 \beta$ treated cells compared to control cells. Therefore, in our in vitro WD model, appropriate concentrations of IL-1 $\beta$ mainly increased expression of c-JUN in SCs nucleus, and promoted de-differentiation and regeneration of SCs.

Among potential intracellular activators of c-JUN is the AP1 transcription complex, of which c-JUN is a key component (Arthur-Farraj et al., 2012). In this study, we analyzed AP-1 activity and found that IL- $1 \beta$ also promoted activation of SC AP-1 in our in vitro WD model. Thus, our findings further reinforce that appropriate concentrations of IL- $1 \beta$ promote dedifferentiation and regeneration of SCs via the c-JUN/AP-1 pathway during the first phase of WD. The c-JUN/AP-1 complex is a prominent downstream nuclear target of ERK, JNK and PI3/AKT pathways (Eriksson et al., 2007; North et al., 2010; Mruthyunjaya et al., 2011). Further studies are required to verify whether IL-1 $\beta$ regulates c-JUN/AP-1 via the ERK, JNK and $\mathrm{PI} 3 / \mathrm{AKT}$ pathways or others.

Ki67 is a nuclear antigen that acts as a specific and sensitive marker of cell proliferation, and it is a reliable indicator for detecting cell proliferation. Ki67 was not expressed in $\mathrm{G}_{0}$ phase and $G_{1}$ early, and began to express in the middle and late $G_{1}$. It was located in the peri-nuclear region, and the expression in $S$ phase and $G_{2}$ phase increased gradually, and M phase peaked (Miller et al., 2018). Therefore, Ki67 is also widely used for pathological evaluation of the proliferation and differentiation of different tumor cells (Berlin et al., 2017). Through Immunofluorescent staining of Ki67 and analysis of percentage of endonuclear $\mathrm{Ki67}(+)$ cells in SCs with or without $5 \mathrm{ng} / \mathrm{ml} \mathrm{IL}-1 \beta$ at $48 \mathrm{~h}$, we found that the appropriate concentration of IL- $1 \beta(5 \mathrm{ng} / \mathrm{ml})$ increased the expression of Ki67 in SCs, and increased the positive rate of Ki67. It can be seen that IL-1 $\beta$ can promote the proliferation of SCs during the process of WD. Furthermore, we used TUNEL to detect and quantify the apoptosis rate in SCs, our study suggested that a specific concentration of IL-1 $\beta(5 \mathrm{ng} / \mathrm{ml})$ inhibited apoptosis in SCs during WD.

\section{CONCLUSION}

Schwann cells of WD produce IL- $1 \beta$ which promotes SCs dedifferentiation and regeneration via the $c$-JUN/AP-1 signaling pathway. SCs of WD produce IL-1 $\beta$ which promotes SCs proliferation and induces inhibition of SCs. The precise molecular mechanisms of IL-1 $\beta$ regulation of c-JUN/AP-1 activity are not fully understood, and further studies are required.

\section{ETHICS STATEMENT}

The study was approved by the Ethics Committee for Animal Research at Shanghai Ninth People's Hospital affiliated to Shanghai JiaoTong University, School of Medicine. In the meantime, in accordance with the approved institutional guidelines and regulations.

\section{AUTHOR CONTRIBUTIONS}

GC conducted this project and wrote the manuscript. XL executed the experiments. WnW and YW participated in data analysis. FZ conceived the plan. WiW initiated this project and proposed the fundamental frame of this project. All authors read and approved the final manuscript.

\section{FUNDING}

This work was supported in part by grants from National Natural Science Foundation of China (81601700), Shanghai Shen-Kang Hospital Development Foundation (16CR3050A), and Shanghai Municipal Commission of Health and Family Planning Foundation (201540253). 


\section{REFERENCES}

Allodi, I., Udina, E., and Navarro, X. (2012). Specificity of peripheral nerve regeneration: interactions at the axon level. Prog. Neurobiol. 98, 16-37. doi: 10.1016/j.pneurobio.2012.05.005

Arthur-Farraj, P. J., Latouche, M., Wilton, D. K., Quintes, S., Chabrol, E., Banerjee, A., et al. (2012). c-Jun reprograms Schwann cells of injured nerves to generate a repair cell essential for regeneration. Neuron 75, 633-647. doi: 10.1016/j. neuron.2012.06.021

Bastien, D., and Lacroix, S. (2014). Cytokine pathways regulating glial and leukocyte function after spinal cord and peripheral nerve injury. Exp. Neurol. 258, 62-77. doi: 10.1016/j.expneurol.2014.04.006

Be'Eri, H., Reichert, F., Saada, A., and Rotshenker, S. (1998). The cytokine network of wallerian degeneration: IL-10 and GM-CSF. Eur. J. Neurosci. 10, 2707-2713. doi: 10.1046/j.1460-9568.1998.00277.x

Berlin, A., Castro-Mesta, J. F., Rodriguez-Romo, L., Hernandez-Barajas, D., Gonzalez-Guerrero, J. F., Rodriguez-Fernandez, I. A., et al. (2017). Prognostic role of Ki-67 score in localized prostate cancer: a systematic review and meta-analysis. Urol. Oncol. 35, 499-506. doi: 10.1016/j.urolonc.2017.05.004

Boerboom, A., Dion, V., Chariot, A., and Franzen, R. (2017). Molecular mechanisms involved in schwann cell plasticity. Front. Mol. Neurosci. 10:38. doi: 10.3389/fnmol.2017.00038

Brosius, L. A., Chung, W. S., Sloan, S. A., Carson, G. A., Zhou, L., Lovelett, E., et al. (2017). Schwann cells use TAM receptor-mediated phagocytosis in addition to autophagy to clear myelin in a mouse model of nerve injury. Proc. Natl. Acad. Sci. U.S.A. 114, E8072-E8080. doi: 10.1073/pnas.1710566114

Chen, Z. L., Yu, W. M., and Strickland, S. (2007). Peripheral regeneration. Annu. Rev. Neurosci. 30, 209-233. doi: 10.1146/annurev.neuro.30.051606.094337

Clement, N., Glorian, M., Raymondjean, M., Andreani, M., and Limon, I. (2006). PGE2 amplifies the effects of IL-1beta on vascular smooth muscle cell dedifferentiation: a consequence of the versatility of PGE2 receptors 3 due to the emerging expression of adenylyl cyclase 8. J. Cell. Physiol. 208, 495-505. doi: $10.1002 /$ jcp. 20673

Eriksson, M., Taskinen, M., and Leppa, S. (2007). Mitogen activated protein kinasedependent activation of c-Jun and c-Fos is required for neuronal differentiation but not for growth and stress response in PC12 cells. J. Cell. Physiol. 210, 538-548. doi: 10.1002/jcp.20907

Gordon, T., Chan, K. M., Sulaiman, O. A., Udina, E., Amirjani, N., and Brushart, T. M. (2009). Accelerating axon growth to overcome limitations in functional recovery after peripheral nerve injury. Neurosurgery 65, A132-A144. doi: 10. 1227/01.NEU.0000335650.09473.D3

Hong, E. H., Song, J. Y., Lee, S. J., Park, I. C., Um, H. D., Park, J. K., et al. (2014). Low-dose gamma-radiation inhibits IL-1beta-induced dedifferentiation and inflammation of articular chondrocytes via blockage of catenin signaling. IUBMB Life 66, 128-137. doi: 10.1002/iub.1248

Hwang, S. G., Yu, S. S., Poo, H., and Chun, J. S. (2005). c-Jun/activator protein-1 mediates interleukin-1beta-induced dedifferentiation but not cyclooxygenase2 expression in articular chondrocytes. J. Biol. Chem. 280, 29780-29787. doi: 10.1074/jbc.M411793200

Jang, S. Y., Yoon, B. A., Shin, Y. K., Yun, S. H., Jo, Y. R., Choi, Y. Y., et al. (2017). Schwann cell dedifferentiation-associated demyelination leads to exocytotic myelin clearance in inflammatory segmental demyelination. Glia 65, 18481862. doi: $10.1002 /$ glia. 23200

Jessen, K. R., and Arthur-Farraj, P. (2019). Repair Schwann cell update: adaptive reprogramming, EMT, and stemness in regenerating nerves. Glia 67, 421-437. doi: $10.1002 /$ glia. 23532

Jessen, K. R., and Mirsky, R. (2008). Negative regulation of myelination: relevance for development, injury, and demyelinating disease. Glia 56, 1552-1565. doi: 10.1002/glia. 20761

Jessen, K. R., and Mirsky, R. (2016). The repair Schwann cell and its function in regenerating nerves. J. Physiol. 594, 3521-3531. doi: 10.1113/JP270874

Jopling, C., Boue, S., and Izpisua, B. J. (2011). Dedifferentiation, transdifferentiation and reprogramming: three routes to regeneration. Nat. Rev. Mol. Cell Biol. 12, 79-89. doi: 10.1038/nrm3043

Lee, H. J., Shin, Y. K., and Park, H. T. (2014). Mitogen activated protein kinase family proteins and c-jun signaling in injury-induced schwann cell plasticity. Exp. Neurobiol. 23, 130-137. doi: 10.5607/en.2014.23.2.130
Lee, H. K., Shin, Y. K., Jung, J., Seo, S. Y., Baek, S. Y., and Park, H. T. (2009). Proteasome inhibition suppresses Schwann cell dedifferentiation in vitro and in vivo. Glia 57, 1825-1834. doi: 10.1002/glia.20894

Martini, R., Fischer, S., Lopez-Vales, R., and David, S. (2008). Interactions between Schwann cells and macrophages in injury and inherited demyelinating disease. Glia 56, 1566-1577. doi: 10.1002/glia.20766

Miller, I., Min, M., Yang, C., Tian, C., Gookin, S., Carter, D., et al. (2018). Ki67 is a graded rather than a binary marker of proliferation versus quiescence. Cell Rep. 24, 1105.e5-1112.e5. doi: 10.1016/j.celrep.2018.06.110

Montaseri, A., Busch, F., Mobasheri, A., Buhrmann, C., Aldinger, C., Rad, J. S., et al. (2011). IGF-1 and PDGF-bb suppress IL-1beta-induced cartilage degradation through down-regulation of NF-kappaB signaling: involvement of Src/PI3K/AKT pathway. PLoS One 6:e28663. doi: 10.1371/journal.pone.0028663

Mruthyunjaya, S., Rumma, M., Ravibhushan, G., Anjali, S., and Padma, S. (2011). c-Jun/AP-1 transcription factor regulates laminin-1-induced neurite outgrowth in human bone marrow mesenchymal stem cells: role of multiple signaling pathways. FEBS Lett. 585, 1915-1922. doi: 10.1016/j.febslet.2011.04.072

North, C. M., Crawford, R. B., Lu, H., and Kaminski, N. E. (2010). 2,3,7,8-tetrachlorodibenzo-p-dioxin-mediated suppression of toll-like receptor stimulated B-lymphocyte activation and initiation of plasmacytic differentiation. Toxicol. Sci. 116, 99-112. doi: 10.1093/toxsci/kfq095

Parkinson, D. B., Bhaskaran, A., Arthur-Farraj, P., Noon, L. A., Woodhoo, A., Lloyd, A. C., et al. (2008). c-Jun is a negative regulator of myelination. J. Cell Biol. 181, 625-637. doi: 10.1083/jcb.200803013

Perry, V. H., Brown, M. C., and Gordon, S. (1987). The macrophage response to central and peripheral nerve injury. A possible role for macrophages in regeneration. J. Exp. Med. 165, 1218-1223. doi: 10.1084/jem.165.4.1218

Raivich, G., Bohatschek, M., Da, C. C., Iwata, O., Galiano, M., Hristova, M., et al. (2004). The AP-1 transcription factor c-Jun is required for efficient axonal regeneration. Neuron 43, 57-67. doi: 10.1016/j.neuron.2004.06.005

Reichert, F., Saada, A., and Rotshenker, S. (1994). Peripheral nerve injury induces Schwann cells to express two macrophage phenotypes: phagocytosis and the galactose-specific lectin MAC-2. J. Neurosci. 14, 3231-3245. doi: 10.1523/ jneurosci.14-05-03231.1994

Rotshenker, S. (2011). Wallerian degeneration: the innate-immune response to traumatic nerve injury. J Neuroinflammation 8:109. doi: 10.1186/1742-20948-109

Rotshenker, S., Aamar, S., and Barak, V. (1992). Interleukin-1 activity in lesioned peripheral nerve. J. Neuroimmunol. 39, 75-80. doi: 10.1016/0165-5728(92) 90176-1

Sasu, S., and Beasley, D. (2000). Essential roles of IkappaB kinases alpha and beta in serum- and IL-1-induced human VSMC proliferation. Am. J. Physiol. Heart Circ. Physiol. 278, H1823-H1831. doi: 10.1152/ajpheart.2000.278.6.H1823

Shamash, S., Reichert, F., and Rotshenker, S. (2002). The cytokine network of Wallerian degeneration: tumor necrosis factor-alpha, interleukin-1alpha, and interleukin-1beta. J. Neurosci. 22, 3052-3060. doi: 10.1523/jneurosci.22-0803052.2002

Shin, Y. K., Jang, S. Y., Park, J. Y., Park, S. Y., Lee, H. J., Suh, D. J., et al. (2013). The Neuregulin-Rac-MKK7 pathway regulates antagonistic c-jun/Krox20 expression in Schwann cell dedifferentiation. Glia 61, 892-904. doi: 10.1002/ glia.22482

Temporin, K., Tanaka, H., Kuroda, Y., Okada, K., Yachi, K., Moritomo, H., et al. (2008a). IL-1beta promotes neurite outgrowth by deactivating RhoA via p38 MAPK pathway. Biochem. Biophys. Res. Commun. 365, 375-380. doi: 10.1016/j. bbrc.2007.10.198

Temporin, K., Tanaka, H., Kuroda, Y., Okada, K., Yachi, K., Moritomo, H., et al. (2008b). Interleukin-1 beta promotes sensory nerve regeneration after sciatic nerve injury. Neurosci. Lett. 440, 130-133. doi: 10.1016/j.neulet.2008. 05.081

Thomson, C. E., Griffiths, I. R., McCulloch, M. C., Kyriakides, E., Barrie, J. A., and Montague, P. (1993). In vitro studies of axonally-regulated Schwann cell genes during Wallerian degeneration. J. Neurocytol. 22, 590-602. doi: 10.1007/ bf01181486

Tricaud, N., and Park, H. T. (2017). Wallerian demyelination: chronicle of a cellular cataclysm. Cell. Mol. Life Sci. 74, 4049-4057. doi: 10.1007/s00018-017-2565-2

Vargas, M. E., and Barres, B. A. (2007). Why is Wallerian degeneration in the CNS so slow? Annu. Rev. Neurosci. 30, 153-179. doi: 10.1146/annurev.neuro. 30.051606.094354 
Voronov, E., Carmi, Y., and Apte, R. N. (2014). The role IL-1 in tumormediated angiogenesis. Front. Physiol. 5:114. doi: 10.3389/fphys.2014. 00114

Warner, L. E., Mancias, P., Butler, I. J., McDonald, C. M., Keppen, L., Koob, K. G., et al. (1998). Mutations in the early growth response 2 (EGR2) gene are associated with hereditary myelinopathies. Nat. Genet. 18, 382-384. doi: 10.1038/ng0498-382

Woszczycka-Korczynska, I., Olakowska, E., Marcol, W., Lewin-Kowalik, J., and Jedrzejowska-Szypulka, H. (2013). [Schwann cells in therapy of spinal cord injuries]. Postepy Hig. Med. Dosw. 67, 680-689. doi: 10.5604/17322693.10 59602

Zhao, Z., Li, X., and Li, Q. (2017). Curcumin accelerates the repair of sciatic nerve injury in rats through reducing Schwann cells apoptosis and promoting myelinization. Biomed. Pharmacother. 92, 1103-1110. doi: 10.1016/j.biopha. 2017.05.099
Zhu, X., Lin, Y., Bacanamwo, M., Chang, L., Chai, R., Massud, I., et al. (2007). Interleukin- 1 beta-induced Id 2 gene expression is mediated by Egr- 1 in vascular smooth muscle cells. Cardiovasc. Res. 76, 141-148. doi: 10.1016/j.cardiores. 2007.06.015

Conflict of Interest Statement: The authors declare that the research was conducted in the absence of any commercial or financial relationships that could be construed as a potential conflict of interest.

Copyright $\odot 2019$ Chen, Luo, Wang, Wang, Zhu and Wang. This is an open-access article distributed under the terms of the Creative Commons Attribution License (CC BY). The use, distribution or reproduction in other forums is permitted, provided the original author(s) and the copyright owner(s) are credited and that the original publication in this journal is cited, in accordance with accepted academic practice. No use, distribution or reproduction is permitted which does not comply with these terms. 